\title{
PENJADWALAN DAN ALOKASI MATERIAL DENGAN METODE LINE OF BALANCE (LOB) PADA PROYEK PELEBARAN JALAN AP.PETTARANI UTARA MAKASSAR
}

\author{
Mohammad Januar Fuad \\ Dosen Program Studi Teknik Sipil STITEK Bina Taruna Gorontalo \\ Indonesia
}

\begin{abstract}
ABSTRAK
Pelebaran Jalan dimaksud untuk menunjang pembangunan di sektor-sektor lain dengan tujuan meningkatkan pertumbuhan ekonomi. Proyek Pelebaran merupakan lingkup pekerjaan dengan biaya yang besar. Sehingga memerlukan perencanaan sumber daya. Penelitian ini bertujuan menghitung jumlah kebutuhan material dan merencanakan waktu penggunaan material di lokasi proyek dengan menggunakan Metode Line of Balance (LOB) pada penyelesaian proyek dan pelaksanaan pekerjaan. Lokasi penelitian Proyek Pelebaran Jalan AP.Pettarani Utara sepanjang $475 \mathrm{~km}$. Data dikumpulkan dengan cara berupa observasi langsung di lapangan. Hasil penelitian menunjukkan bahwa penjadwalan dan alokasi material dengan menggunakan metode Line of balance (LOB), bisa diketahui dengan lebih detail waktu pelaksanaan pekerjaan tiap stasiun disertai kebutuhan tiap stasiun. Metode Line of Balance (LOB) adalah metode yang sederhana tapi sangat praktis dan tepat untuk proyek konstruksi jalan karena dengan metode ini bisa pekerjaan yang bisa dilaksanakan tanpa berpatok pada perencanaan dala kurva ' $S$ '. Durasi hari kerja bisa dipercepat dengan meningkatkan produktivitas sumber daya peralatan dan tenaga kerja.
\end{abstract}

Kata Kunci: Metode Line of Balance (LOB), Konstruksi Jalan

\section{Pendahuluan}

Program pemerintah dalam

pembangunan bidang infrastruktur

Proyek Pelebaran Jalan A.P. dimaksudkan agar dapat menunjang Pettarani Kota Makassar Provinsi Sulawesi pembangunan di sektor-sektor lain seperti Selatan merupakan salah satu kebijakan dari diupayakannya perbaikan jalan-jalan yang Pemerintah Indonesia melalui Kementerian telah rusak (tidak layak dari segi konstruksi) Pekerjaan Umum, Direktorat Jenderal Bina atau ditingkatkan lagi sehingga dapat melayani arus lalu lintas yang semakin meningkat. Marga. Ditinjau dari lingkup pekerjaan dan besarnya biaya, proyek ini termasuk berskala besar sehingga memerlukan perencanaan sumber daya. Pihak pelaksana 
proyek telah melakukan persiapan-persiapan berupa perencanaan dan pengalokasian material untuk pelaksanaan pekerjaan. Mengingat bahwa material yang digunakan dalam perkerasan jalan sangat penting dan konstribusinya cukup besar (dominan) pada proyek ini, maka sangat diperlukan tindakan efisiensi dengan cara mendayagunakan seluruh sumber daya material.

Dengan pertimbangan-pertimbangan tersebut, maka penelitian bertujuan menghitung jumlah kebutuhan material dan merencanakan waktu penggunaan material di lokasi proyek dengan menggunakan Metode Line of Balance (LOB) pada penyelesaian proyek dan pelaksanaan pekerjaan.

\section{Metode Penelitian}

\section{Lokasi Penelitian}

Proyek yang diamati adalah Proyek Pelebaran Jalan AP.Pettarani Utara sepanjang $475 \mathrm{~km}$.

\section{Data yang dikumpulkan}

Data yang dikumpulkan antara lain berupa observasi langsung di lapangan mengenai hal-hal yang mempengaruhi penjadwalan dan pengalokasian alat berat seperti waktu, jarak dan kondisi medan pekerjaan. Selain data observasi langsung di lapangan, diperoleh juga data berupa $\mathrm{RAB}$, gambaran umum proyek, serta data-data lain yang diperoleh melalui wawancara langsung dengan berbagai pihak di lapangan.

\section{Analisis Perencanaan Kebutuhan dan Penjadwalan Material dengan Menggunakan Metode Line Of Balance (LOB)}

\section{Uraian Pekerjaan}

\subsection{Rincian Volume dan Jenis Pekerjaan}

Item pekerjaan yang berbobot besar merupakan item penting dalam kontruksi jalan. Besarnya volume pekerjaan pada proyek ini adalah berdasarkan data yang kami peroleh dari kontraktor. Volume item pekerjaan yang akan dibahas ditampilkan di Tabel 1. 
Tabel 1. Kebutuhan Material

\begin{tabular}{|c|c|c|c|c|c|c|c|c|}
\hline No & Uraian Pelerjaen Utama & $\begin{array}{l}\text { Vollume } \\
\text { Peloerjaan } \\
\text { Utama }\end{array}$ & Sat. & $\begin{array}{c}\text { Bobot } \\
139\end{array}$ & Majerial Yang Digunalen & $\begin{array}{c}\text { Volume } \\
\text { MateriallYang } \\
\text { Dbutuhkican }\end{array}$ & Sat. & $\begin{array}{c}\text { Bo bot } \\
\text { Maserial } \\
\text { c39 }\end{array}$ \\
\hline 1 & Pelerjan Tanah & & & & & & & \\
\hline & $\begin{array}{l}\text { Timounan Base } \\
\text { Timoungn Pihan }\end{array}$ & $\begin{array}{l}173.31 \\
96.63\end{array}$ & \begin{tabular}{c|}
$m 3$ \\
$m 3$
\end{tabular} & $\begin{array}{l}0.388 \\
0.297\end{array}$ & $\begin{array}{l}\text { Tangh } \\
\text { Sru }\end{array}$ & $\begin{array}{l}173.31 \\
\text { sse3 }\end{array}$ & $m$ & $\begin{array}{r}100 \\
100 \\
\end{array}$ \\
\hline 2 & Pentoerasan Berbusir & & & & & & & \\
\hline & $\begin{array}{l}\text {-apisen Fondas agrega:kelas A } \\
\text {-apisen Fondasi agrega:kelas } \mathrm{A}\end{array}$ & $\begin{array}{l}640.31 \\
83229\end{array}$ & m3 & $\begin{array}{l}3.77 \\
\text { a. } 182\end{array}$ & 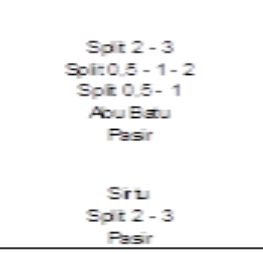 & $\begin{array}{l}2008190 \\
1486313 \\
1163308 \\
909408 \\
778672 \\
\\
332916 \\
416148 \\
83229 \\
\end{array}$ & \begin{tabular}{l|}
$m$ \\
$m$ \\
$m$ \\
$m B$ \\
$m$ \\
$m$ \\
$m$ \\
$m$ \\
$m$
\end{tabular} & $\begin{array}{l}32 \\
23 \\
18 \\
15 \\
12 \\
\\
40 \\
30 \\
10 \\
\end{array}$ \\
\hline 3 & Perioerasan Jalan & & & & & & & \\
\hline & 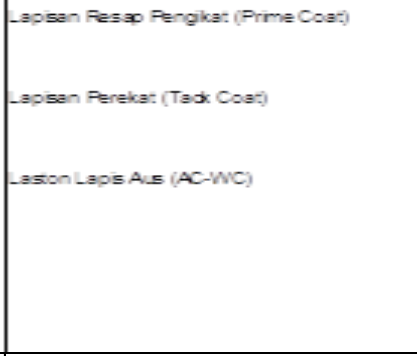 & $\begin{array}{l}2.300 .10 \\
1.480 .31 \\
1,792.39\end{array}$ & \begin{tabular}{l|}
$\operatorname{Lr}$ \\
$\operatorname{Lan}$ \\
$\operatorname{Ta}$
\end{tabular} & $\begin{array}{l}1.10 \\
2968 \\
11267\end{array}$ & 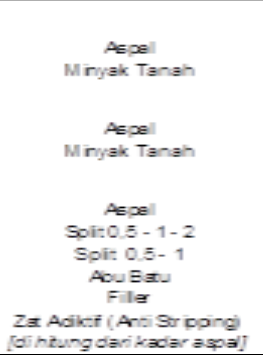 & 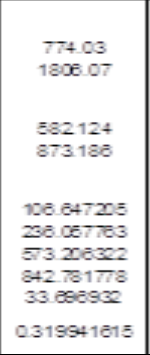 & $\begin{array}{l}\text { Lr } \\
\text { ir } \\
\text { Lx } \\
\text { ix } \\
\text { Ton } \\
\text { Ton } \\
\text { Ton } \\
\text { Ton } \\
\text { Ton }\end{array}$ & $\begin{array}{l}30 \\
70 \\
\\
40 \\
60 \\
\\
5.96 \\
13.17 \\
31.98 \\
47.98 \\
1.88 \\
0.3\end{array}$ \\
\hline & $\begin{array}{l}\text { Laston Lapis Antara (AC-BC) Levelling } \\
\text { Laston Lapis Pondasi (AC-Base) }\end{array}$ & $\begin{array}{l}1,878.55 \\
435.41\end{array}$ & $\begin{array}{l}\text { Ton } \\
\text { Ton }\end{array}$ & $\begin{array}{r}14.984 \\
12.225 \\
\end{array}$ & $\begin{array}{c}\text { Aspal } \\
\text { Split } 2-3 \\
\text { Split } 0,5-1-2 \\
\text { Split } 0,5-1 \\
\text { Abu Batu } \\
\text { Filler } \\
\\
\text { Aspal } \\
\text { Split } 2-3 \\
\text { Split } 0,5-1-2 \\
\text { Split } 0,5-1 \\
\text { Abu Batu } \\
\text { Filler } \\
\end{array}$ & $\begin{array}{c}101.4417 \\
159.864605 \\
302.07084 \\
497.627895 \\
782.040365 \\
35.504595 \\
\\
\\
21.33509 \\
70.405797 \\
95.224167 \\
107.676893 \\
132.495263 \\
8.27279 \\
\end{array}$ & $\begin{array}{l}\text { Ton } \\
\text { Ton } \\
\text { Ton } \\
\text { Ton } \\
\text { Ton } \\
\text { Ton } \\
\\
\text { Ton } \\
\text { Ton } \\
\text { Ton } \\
\text { Ton } \\
\text { Ton } \\
\text { Ton } \\
\end{array}$ & $\begin{array}{c}5.4 \\
8.51 \\
16.08 \\
26.49 \\
41.63 \\
1.89 \\
\\
4.9 \\
16.17 \\
21.87 \\
24.73 \\
30.43 \\
1.9 \\
\end{array}$ \\
\hline 4 & Struktur & & & & & & & \\
\hline & $\begin{array}{l}\text { Beton Mutu Sedang dgn fc'=15 Mpa (k175) } \\
\text { Baja Tulangan U24 Polos } \\
\text { Kerb Pracetak }\end{array}$ & $\begin{array}{c}157.6 \\
\\
\\
448.04 \\
6780,96\end{array}$ & $\begin{array}{l}\mathrm{m3} \\
\mathrm{kg} \\
\mathrm{bh}\end{array}$ & 1.723 & $\begin{array}{l}\text { PC } \\
\text { Pasir } \\
\text { Split } 1 \text { - } 2 \\
\text { Split } 2 \text { - } 3 \\
\quad \text { Air }\end{array}$ & $\begin{array}{c}52.1656 \\
119.776 \\
87.572016 \\
74.598384 \\
32,308\end{array}$ & $\begin{array}{l}\text { Ton } \\
\text { Ton } \\
\text { Ton } \\
\text { Ton } \\
\text { Ltr }\end{array}$ & \\
\hline
\end{tabular}

\subsection{Perhitungan Kebutuhan Material Setiap} Stasiun (STA).

Dalam menghitung penjadwalan dan alokasi material perlu dihitung volume kebutuhan material setiap stasiun (STA). Selain itu, ada beberapa hal yang mempengaruhi faktor volume material di lapangan misalnya:
- Faktor pemadatan material ( dikali 1,2 dari volume lapangan )

- Faktor kehilangan material ( dikali 0,1 dari volume lapangan )

Perhitungan volume yang dibutuhkan pada setiap stasiun dapat dihitung berdasarkan item 
pekerjaan yang ditinjau dengan persamaan dibawah ini :

\section{a. Timbunan Biasa}

b. Timbunan Pilihan

Jarak antar stasiun $\mathrm{x}$ lebar rata-rata antar stasiun $\mathrm{x}$ tebal rata-rata antar stasiun

\section{c. Agregat Kelas B}

Jarak antar stasiun $\mathrm{x}$ lebar rata-rata antar stasiun $\mathrm{x}$ tebal rata-rata antar stasiun

\section{d. Agregat Kelas A}

Jarak antar stasiun $\mathrm{x}$ lebar rata-rata antar stasiun $\mathrm{x}$ tebal rata-rata antar stasiun

\section{e. Prime Coat (Resap Pengikat)}

Luas (jarak antar stasiun $\mathrm{x}$ lebar ratarata antar stasiun) $\mathrm{x}$ aspal mix

\section{f. Tack Coat (Lapis Perekat)}

Luas (jarak antar stasiun $\mathrm{x}$ lebar ratarata antar stasiun) $\mathrm{x}$ koefisien aspal untuk tiap lapisan yang direkatkan

g. Laston Lapis Pondasi ( AC Base )

Jarak antar stasiun $\mathrm{x}$ lebar rata-rata antar stasiun $\mathrm{x}$ tebal rata-rata antar stasiun $\mathrm{x}$ berat jenis Aspal

\section{h. Laston Lapis Antara ( AC - BC )}

Jarak antar stasiun $\mathrm{x}$ lebar rata-rata antar stasiun $\mathrm{x}$ tebal rata-rata antar stasiun $\mathrm{x}$ berat jenis Aspal

i. Laston Lapis Aus ( AC - WC )
Jarak antar stasiun $\mathrm{x}$ lebar rata-rata antar stasiun $\mathrm{x}$ tebal rata-rata antar stasiun

Jarak antar stasiun $\mathrm{x}$ lebar rata-rata antar stasiun $\mathrm{x}$ tebal rata-rata antar stasiun $\mathrm{x}$ berat jenis Aspal

j. Beton k175 (Pekerjaan Trotoar, Separator dan Median)

Jarak antar stasiun $\mathrm{x}$ lebar rata-rata antar stasiun $\mathrm{x}$ tebal rata-rata antar stasiun

\section{k. Baja Tulangan U24 polos}

Jumlah tulangan yang dibutuhkan $\mathrm{X}$ berat tulangan tiap buahnya

I. Kerb (Trotoar, Median dan Separator)

Diketahui bahwa kerb pada median terdiri dari dua lapis bagian untuk tiap sisinya dan untuk trotoar dan separator hanya terdapat satu lapisan. Sehingga didapat perhitungan jumlah kebutuhan kerb tiap stasiun adalah:

Jarak antar stasiun

Panjang kerb $\mathrm{x} 4$

\subsection{Penjadwalan dan Alokasi Material dengan Metode Line of Balance}

Pada proyek ini pekerjaan dilakukan hanya berdasar pada schedule kurva ' $\mathrm{S}$ ', agar lebih mendetail analisa dilakukan menggunakan metode penjadwalan linear (Line of Balance) dengan memplot durasi perencanaan kurva ' $\mathrm{S}$ ', terhadap stasiun 
kerja dilapangan sehingga diperoleh diagram vektor untuk setiap item pekerjaan.

Pada pelaksanaan di lokasi, proyek ini dilaksanakan dalam kota dimana tidak bisa dilakukan secara bersamaan tiap jalur, karena dipengaruhi faktor kemacetan, maka pada pelaksanaannya dibagi atas dua bagian, jalur kanan jalan A.P. Pettarani dilaksanakan lebih dahulu daripada jalur kiri. Sehingga diagram vector dibagi menjadi dua bagian yakni bagian kanan dan bagian kiri.

Dalam menggunakan metode ini dilakukan beberapa akselerasi pada beberapa item pekerjaan untuk menghindari penumpukan beberapa jenis material pada stasiun (STA) lokasi yang merupakan bentuk sistem dari Metode Line of Balance (LOB) Gambar 1.

Setelah menyelesaikan pembuatan diagram vector, waktu yg dibutuhkan untuk menyediakan kebutuhan material setiap stasiun bisa didapat dengan memasukan volume pekerjaan pada stasiun kerja yg telah dihitung sebelumnya dengan waktu yg didapat pada diagram vector seperti pada Tabel 2 dan seterusnya.

Dengan demikian didapatlah kebutuhan material yang lebih rinci pada setiap stasiun kerja dengan waktu penyedian material tersebut. Sehingga pengadaan dan pemakaian material terlaksanakan dengan lebih efesiensi dan ekonomis.

\section{Kesimpulan}

Berdasarkan hasil Penjadwalan dan Alokasi Material yang dilakukan pada proyek pembangunan jalan tersebut, maka diperoleh kesimpulan sebagai berikut :

1. Dari hasil Penjadwalan dan Alokasi Material dengan menggunakan metode Line of balance (LOB), bisa diketahui dengan lebih detail waktu pelaksanaan pekerjaan tiap stasiun disertai kebutuhan tiap stasiun.

2. Metode Line of Balance (LOB) adalah metode yang sederhana tapi sangat praktis dan tepat untuk proyek konstruksi jalan karena dengan metode ini bisa pekerjaan yang bisa dilaksanakan tanpa berpatok pada perencanaan dala kurva 'S'.

Durasi hari kerja bisa dipercepat dengan meningkatkan produktivitas sumber daya peralatan dan tenaga kerja. 
RADIAL - juRnal perADaban saIns, rekayAsa dan teknoLogi Sekolah Tinggi Teknik (STITEK) Bina Taruna Gorontalo VOLUME 7 NO. 2 Desember 2019

Gambar 1. Diagram Linier / Line of Balance (LOB)
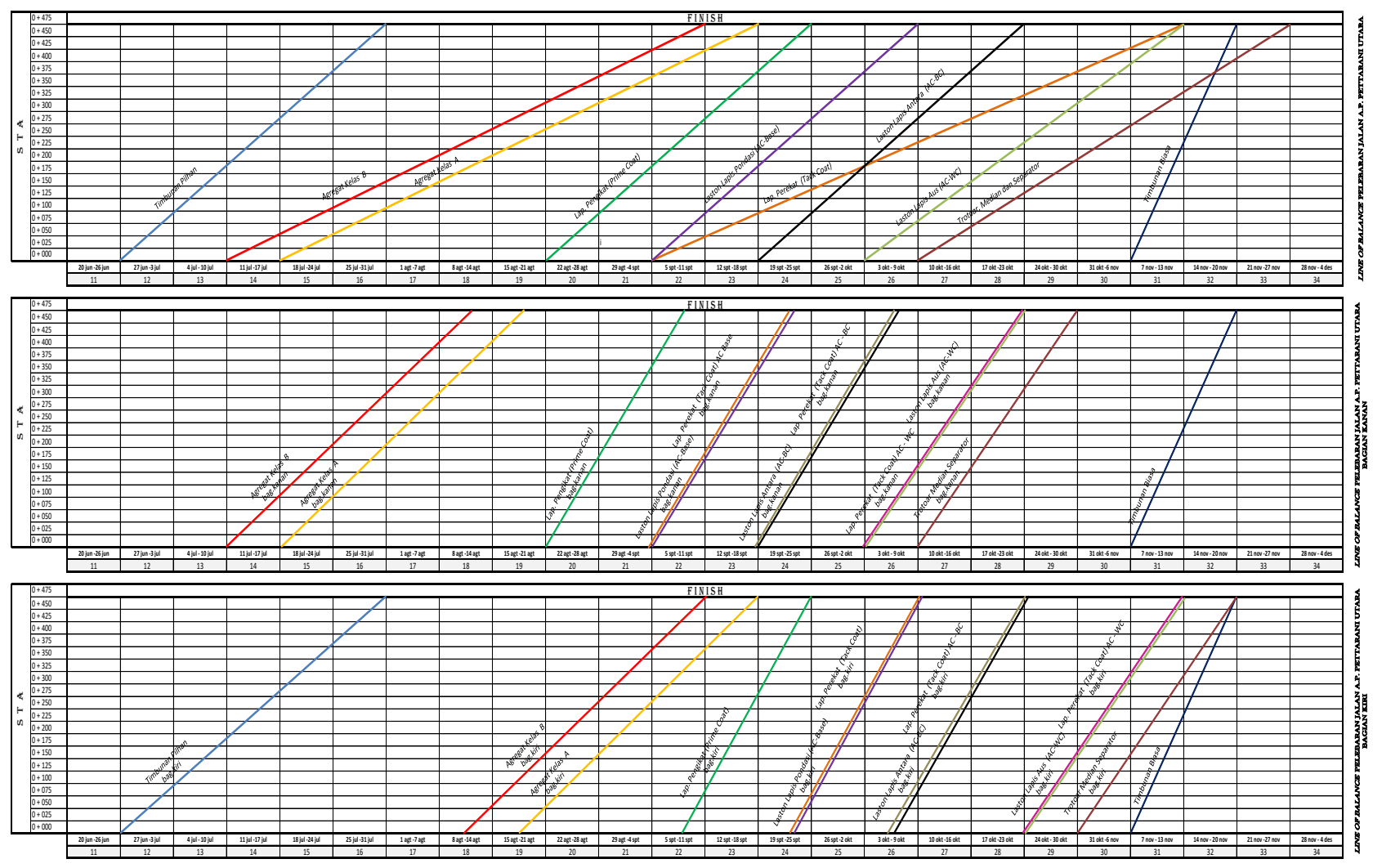
RADIAL - juRnal perADaban saIns, rekayAsa dan teknoLogi Sekolah Tinggi Teknik (STITEK) Bina Taruna Gorontalo VOLUME 7 NO. 2 Desember 2019

Tabel.2

\begin{tabular}{|c|c|c|c|c|c|c|c|c|c|c|c|c|c|c|c|c|c|c|c|c|c|c|}
\hline \multirow[b]{2}{*}{ Jenis Pekerjaan: Timbunan Pilihan } & \multirow[b]{2}{*}{ Total Volume } & \multirow[b]{2}{*}{ Sat. } & \multicolumn{20}{|c|}{ ST A } \\
\hline & & & $\begin{array}{l}8 \\
\text { ¿ } \\
\vdots \\
\end{array}$ & $\begin{array}{l}\stackrel{N}{N} \\
0 \\
\vdots \\
0\end{array}$ & $\begin{array}{l}\text { 오 } \\
\text { น̂ } \\
\text { 士 }\end{array}$ & $\begin{array}{l}\text { nn } \\
\hat{0} \\
0 \\
0 \\
0\end{array}$ & \begin{tabular}{l}
8 \\
\multirow{-1}{0}{} \\
$\vdots$
\end{tabular} & \begin{tabular}{l}
$\stackrel{n}{7}$ \\
\multirow{1}{+}{}
\end{tabular} & \begin{tabular}{l}
0 \\
$\stackrel{0}{n}$ \\
\multirow{1}{*}{} \\
0
\end{tabular} & \begin{tabular}{l} 
n \\
\multirow{7}{+}{} \\
0
\end{tabular} & 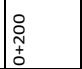 & 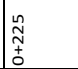 & 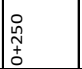 & 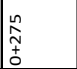 & 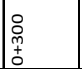 & $\begin{array}{l}\stackrel{n}{N} \\
\tilde{m} \\
0\end{array}$ & 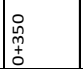 & $\begin{array}{l}\text { n } \\
\text { m } \\
\text { d }\end{array}$ & $\begin{array}{l}8 \\
8 \\
+ \\
\vdots \\
0\end{array}$ & \begin{tabular}{l}
$\stackrel{n}{\mathcal{N}}$ \\
\multirow{+}{+}{} \\
0
\end{tabular} & $\begin{array}{l}\text { O } \\
\text { ڤn } \\
\vdots \\
\vdots\end{array}$ & 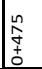 \\
\hline \multirow{6}{*}{ Sirtu } & 0 & m3 & & & & & & & & & & & & & & & & & & & & $\pi$ \\
\hline & \multicolumn{2}{|c|}{ Waktu Penyiapan } & & & & & & & & & & & & & & & & & & & & + \\
\hline & \multicolumn{2}{|c|}{ Volume Penyiapan } & & & & & & & & & & & & & & & & & & & & U \\
\hline & 98.65 & \begin{tabular}{|l|}
$\mathrm{m} 3$ \\
\end{tabular} & $\overline{\text { Kiri }}$ & Kiri & Kiri & Kiri & Kiri & Kiri & $\overline{\text { Kiri }}$ & Kiri & $\overline{\text { Kiri }}$ & Kiri & Kiri & Kiri & Kiri & Kiri & Kiri & Kiri & Kiri & Kiri & Kiri & $=$ \\
\hline & \multicolumn{2}{|c|}{\begin{tabular}{|l|l} 
Waktu Penyiapan & \\
\end{tabular}} & $26 / 6 / 11$ & $26 / 6 / 11$ & $26 / 6 / 11$ & 26/6/11 & $26 / 6 / 11$ & $26 / 6 / 11$ & $5 / 7 / 2011$ & $5 / 7 / 2011$ & $5 / 7 / 2011$ & $5 / 7 / 2011$ & $5 / 7 / 2011$ & $5 / 7 / 2011$ & 18/7/11 & 18/7/11 & 18/7/11 & 18/7/11 & 18/7/11 & $18 / 7 / 11$ & 18/7/11 & $z$ \\
\hline & \multicolumn{2}{|c|}{ Volume Penyiapan } & 6.25 & 7.13 & 6.25 & 5.75 & 4.75 & 4.13 & 4.25 & 5.25 & 6 & 5.63 & 4.38 & 3.75 & 3.75 & 4.38 & 6.75 & 7.5 & 6.5 & 3.25 & 3 & - \\
\hline \multirow[b]{2}{*}{$\begin{array}{c}\text { Jenis Pekerjaan: Lapisan Pondasi } \\
\text { Agregat Kelas B }\end{array}$} & \multirow[b]{2}{*}{ Total Volume } & \multirow[b]{2}{*}{ Sat. } & \multicolumn{20}{|c|}{ S T A } \\
\hline & & & 道 & $\begin{array}{l}\stackrel{n}{n} \\
\vdots \\
⿱ \\
0\end{array}$ & $\begin{array}{l}0 \\
0 \\
0 \\
0 \\
0\end{array}$ & $\begin{array}{l}n \\
n \\
0 \\
0 \\
0\end{array}$ & 章 & $\underset{\substack{n \\
⿱ \\
+}}{2}$ & 荺 & $\begin{array}{l}n \\
\hat{1} \\
0 \\
0\end{array}$ & 每 & 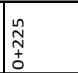 & 总 & $\begin{array}{l}n \\
\hat{n} \\
\vdots \\
0\end{array}$ & $\begin{array}{l}8 \\
0 \\
0 \\
0\end{array}$ & $\begin{array}{l}\stackrel{n}{N} \\
0 \\
0\end{array}$ & 足 & $\begin{array}{l}n \\
\hat{m} \\
0 \\
0\end{array}$ & $\begin{array}{l}8 \\
\vdots \\
\vdots \\
\vdots \\
0\end{array}$ & \begin{tabular}{l}
$n$ \\
\multirow{1}{0}{} \\
0
\end{tabular} & 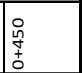 & 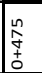 \\
\hline \multirow{5}{*}{ Agregat Kelas B } & 270.57 & m3 & Kanan & Kanan & Kanan & Kanan & Kanan & Kanan & Kanan & Kanan & Kanan & Kanan & Kanan & Kanan & Kanan & Kanan & Kanan & Kanan & Kanan & Kanan & Kanan & $x$ \\
\hline & \multicolumn{2}{|c|}{ Waktu Penyiapan } & $10 / 07 / 11$ & $\mid 10 / 07 / 11$ & $10 / 07 / 11$ & $10 / 07 / 11$ & $10 / 07 / 11$ & $10 / 07 / 11$ & $\mid 19 / 07 / 11$ & 19/07/11 & $19 / 07 / 11$ & 19/07/11 & $\mid 19 / 07 / 11$ & $19 / 07 / 11$ & $27 / 07 / 11$ & $27 / 07 / 11$ & $27 / 07 / 11$ & $27 / 07 / 11$ & $27 / 07 / 11$ & $27 / 07 / 11$ & $27 / 07 / 11$ & \\
\hline & \multicolumn{2}{|c|}{ Volume Penyiapan } & 20.47 & 20.01 & 16.07 & 18.76 & 17.19 & 13.47 & 9.93 & 16.88 & 14.08 & 25.94 & 13.83 & 14.5 & 14.92 & 3.13 & 3.13 & 3.13 & 14.63 & 22.56 & 7.94 & \\
\hline & 561.72 & $\mathrm{~m} 3$ & Kiri & Kiri & Kiri & Kiri & Kiri & Kiri & Kiri & Kiri & Kiri & Kiri & Kiri & Kiri & Kiri & Kiri & Kiri & Kiri & Kiri & Kiri & Kiri & $=$ \\
\hline & \multicolumn{2}{|c|}{ Volume Penyiapan } & 54.07 & 52.19 & 50.7 & 36.57 & 23.59 & 25.96 & 6.33 & 3.13 & 18.84 & 25.01 & 7.31 & 32 & 33.44 & 22.89 & 42.19 & 42.19 & 33.13 & 25.81 & 26.37 & - \\
\hline Total Kebutuhan & 832.29 & m3 & 74.54 & 72.2 & 66.77 & 55.33 & 40.78 & 39.43 & 16.26 & 20.01 & 32.92 & 50.95 & 21.14 & 46.5 & 48.36 & 26.02 & 45.32 & 45.32 & 47.76 & 48.37 & 34.31 & 4 \\
\hline \multirow[b]{2}{*}{$\begin{array}{c}\text { Jenis Pekerjaan: Lapisan Pondasi } \\
\text { Agregat Kelas A }\end{array}$} & \multirow[b]{2}{*}{ Total Volume } & \multirow[b]{2}{*}{ Sat. } & \multicolumn{20}{|c|}{ S T A } \\
\hline & & & $\begin{array}{l}8 \\
0 \\
0 \\
\end{array}$ & 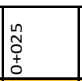 & $\begin{array}{l}\text { 오 } \\
\text { ڤn } \\
\text { † } \\
\end{array}$ & $\begin{array}{l}\text { 战 } \\
0 \\
⿱ \\
0 \\
\end{array}$ & \begin{tabular}{l}
8 \\
\multirow{-1}{+}{} \\
\pm \\
\end{tabular} & \begin{tabular}{l}
$\stackrel{n}{N}$ \\
\multirow{+}{+}{} \\
\end{tabular} & 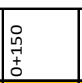 & $\begin{array}{l}n \\
\hat{1} \\
0 \\
0\end{array}$ & $\begin{array}{l}8 \\
\substack{0 \\
0 \\
0}\end{array}$ & 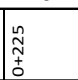 & \begin{tabular}{l}
0 \\
$\stackrel{0}{n}$ \\
\multirow{2}{0}{}
\end{tabular} & $\begin{array}{l}\stackrel{n}{\Lambda} \\
\sim \\
0\end{array}$ & $\begin{array}{l}8 \\
0 \\
0 \\
0\end{array}$ & $\begin{array}{l}\stackrel{n}{N} \\
0 \\
0\end{array}$ & 总 & $\begin{array}{l}n \\
0 \\
0 \\
0 \\
0\end{array}$ & $\begin{array}{l}8 \\
\vdots \\
\vdots \\
\vdots \\
0\end{array}$ & 古 & 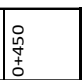 & 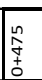 \\
\hline \multirow{6}{*}{ Agregat Kelas A } & 230.59 & m3 & Kanan & Kanan & Kanan & Kanan & Kanan & Kanan & Kanan & Kanan & Kanan & Kanan & Kanan & Kanan & Kanan & Kanan & Kanan & Kanan & Kanan & Kanan & Kanan & $=$ \\
\hline & \multicolumn{2}{|c|}{ Waktu Penyiapan } & $17 / 07 / 11$ & 17/07/11 & $17 / 07 / 11$ & $17 / 07 / 11$ & $17 / 07 / 11$ & $17 / 07 / 11$ & 27/07/11 & $27 / 07 / 11$ & $27 / 07 / 11$ & $27 / 07 / 11$ & 27/07/11 & $27 / 07 / 11$ & 06/08/11 & $06 / 08 / 11$ & 06/08/11 & 06/08/11 & 06/08/11 & $06 / 08 / 11$ & 06/08/11 & \\
\hline & Volume Penyia & & 16.38 & 16 & 12.85 & 15 & 13.5 & 10.77 & 7.94 & 13.75 & 11.26 & 20.75 & 11.04 & 11.6 & 11.93 & 2.5 & 2.5 & 2.5 & 11.7 & 16.02 & 22.6 & $n$ \\
\hline & 415.72 & m3 & Kiri & Kiri & Kiri & Kiri & Kiri & Kiri & Kiri & Kiri & Kiri & Kiri & Kiri & Kiri & Kiri & Kiri & Kiri & Kiri & Kiri & Kiri & Kiri & \\
\hline & Waktu Penyia & & 18/08/11 & 18/08/11 & $18 / 08 / 11$ & $18 / 08 / 11$ & $18 / 08 / 11$ & $18 / 08 / 11$ & $27 / 08 / 11$ & $27 / 08 / 11$ & $27 / 08 / 11$ & $27 / 08 / 11$ & $27 / 08 / 11$ & $27 / 08 / 11$ & 08/09/11 & 08/09/11 & 08/09/11 & 08/09/11 & 08/09/11 & $08 / 09 / 11$ & $08 / 09 / 11$ & \\
\hline & Volume Penyia & & 43.25 & 39 & 30.1 & 29.25 & 18.87 & 20.76 & 5.06 & 2.5 & 14.91 & 20 & 5.85 & 24.6 & 26.75 & 18.32 & 33.75 & 33.75 & 26.5 & 20.65 & 1.85 & - \\
\hline Total Kebutuhan & 646.31 & m3 & 59.63 & 55 & 42.95 & 44.25 & 32.37 & 31.53 & 13 & 16.25 & 26.17 & 40.75 & 16.89 & 36.2 & 38.68 & 20.82 & 36.25 & 36.25 & 38.2 & 36.67 & 24.45 & 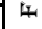 \\
\hline
\end{tabular}

\begin{tabular}{|c|c|c|c|c|c|c|c|c|c|c|c|c|c|c|c|c|c|c|c|c|c|c|}
\hline \multirow[b]{2}{*}{ Jenis Pekerjaan: Lapis Resap Pengikat } & \multirow[b]{2}{*}{ Total Volume } & \multirow[b]{2}{*}{ Sat. } & \multicolumn{20}{|c|}{ ST A } \\
\hline & & & $\begin{array}{l}8 \\
0 \\
\vdots \\
0\end{array}$ & 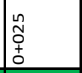 & $\begin{array}{l}0 \\
\text { on } \\
\text { 1 } \\
\end{array}$ & \begin{tabular}{|l}
$n$ \\
0 \\
0 \\
$\vdots$ \\
0
\end{tabular} & $\begin{array}{l}8 \\
\vdots \\
0 \\
0\end{array}$ & \begin{tabular}{l}
$\stackrel{n}{0}$ \\
\multirow{1}{0}{} \\
0
\end{tabular} & \begin{tabular}{l}
0 \\
0 \\
\multirow{1}{0}{} \\
0
\end{tabular} & $\begin{array}{l}n \\
\hat{n} \\
0 \\
0\end{array}$ & \begin{tabular}{l}
8 \\
\multirow{2}{0}{} \\
0 \\
0
\end{tabular} & 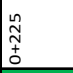 & $\begin{array}{l}0 \\
\stackrel{N}{1} \\
\text { D }\end{array}$ & 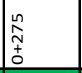 & $\begin{array}{l}0 \\
0 \\
\vdots \\
0\end{array}$ & $\begin{array}{l}\stackrel{n}{2} \\
\tilde{1} \\
0 \\
\end{array}$ & $\begin{array}{l}0 \\
0 \\
0 \\
0 \\
0\end{array}$ & $\begin{array}{l}n \\
\hat{m} \\
0 \\
0\end{array}$ & $\begin{array}{l}8 \\
\vdots \\
\vdots \\
0\end{array}$ & \begin{tabular}{l} 
N \\
\multirow{1}{\pm}{} \\
0
\end{tabular} & $\begin{array}{l}0 \\
\not \begin{array}{l}0 \\
\vdots \\
\vdots\end{array}\end{array}$ & 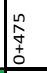 \\
\hline \multirow{6}{*}{ Prime Coat } & 1041.87 & Liter & Kanan & Kanan & Kanan & Kanan & Kanan & Kanan & Kanan & Kanan & Kanan & Kanan & Kanan & Kanan & Kanan & Kanan & Kanan & Kanan & Kanan & Kanan & Kanan & $\bar{T}$ \\
\hline & \multicolumn{2}{|c|}{ Waktu Penyiapan } & $21 / 08 / 11$ & $21 / 08 / 11$ & $21 / 08 / 11$ & 21/08/11 & $21 / 08 / 11$ & $26 / 08 / 11$ & $26 / 08 / 11$ & $26 / 08 / 11$ & 26/08/11 & $26 / 08 / 11$ & $30 / 08 / 11$ & $30 / 08 / 11$ & $30 / 08 / 11$ & 30/08/11 & $30 / 08 / 11$ & $03 / 09 / 11$ & $03 / 09 / 11$ & $03 / 09 / 11$ & $03 / 09 / 11$ & + \\
\hline & \multicolumn{2}{|c|}{ Volume Penyiapan } & 62 & 64 & 71.9 & 94.5 & 93 & 61.4 & 30.2 & 48 & 71.68 & 140.5 & 59.36 & 54.23 & 32.54 & 10 & 10 & 10 & 22.42 & 50.74 & 55.4 & d. \\
\hline & 1538.23 & Liter & Kiri & Kiri & Kiri & $\overline{\text { Kiri }}$ & Kiri & $\overline{\text { Kiri }}$ & Kiri & Kiri & Kiri & Kiri & Kiri & Kiri & Kiri & Kiri & Kiri & Kiri & Kiri & Kiri & Kiri & 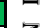 \\
\hline & \multicolumn{2}{|c|}{ Waktu Penyiapan } & 07/09/11 & 07/09/11 & 07/09/11 & 12/09/11 & $12 / 09 / 11$ & $12 / 09 / 11$ & 12/09/11 & $17 / 09 / 11$ & 17/09/11 & $17 / 09 / 11$ & 17/09/11 & 22/09/11 & 22/09/11 & $22 / 09 / 11$ & 22/09/11 & $27 / 09 / 11$ & $27 / 09 / 11$ & $27 / 09 / 11$ & $27 / 09 / 11$ & \\
\hline & \multicolumn{2}{|c|}{ Volume Penyiapan } & 99 & 114 & 100.4 & 108 & 69.45 & 83.04 & 22.8 & 10 & 55.7 & 62 & 16.64 & 115.2 & 138 & 148 & 129 & 108 & 86 & 41.6 & 31.4 & - \\
\hline
\end{tabular}


RADIAL - juRnal perADaban saIns, rekayAsa dan teknoLogi Sekolah Tinggi Teknik (STITEK) Bina Taruna Gorontalo VOLUME 7 NO. 2 Desember 2019

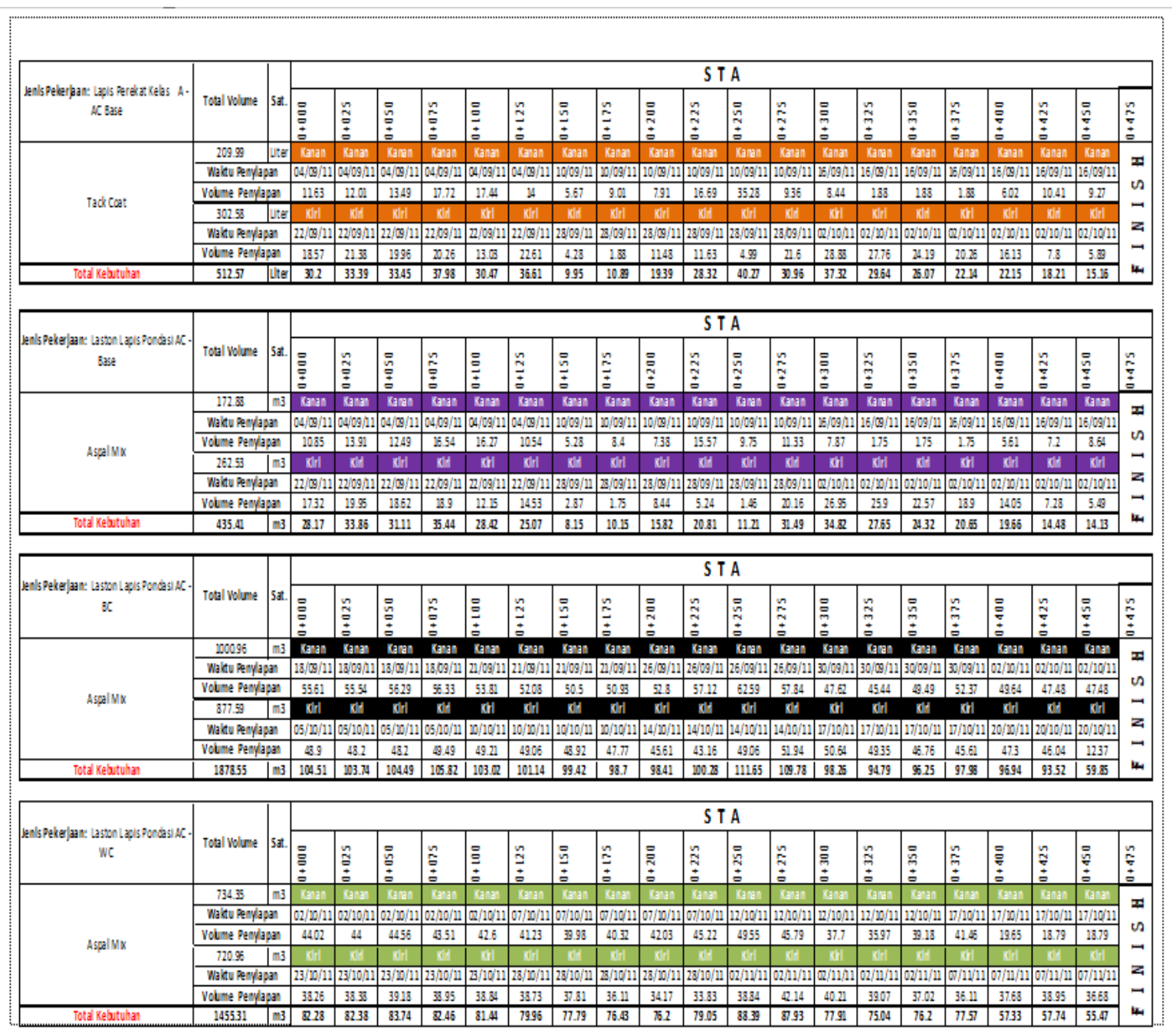

[Penjadwalan dan alokasi material dengan metode (lob) pada proyek pelebaran jalan : ....; Mohamad Januar Fuad] 
RADIAL - juRnal perADaban saIns, rekayAsa dan teknoLogi

Sekolah Tinggi Teknik (STITEK) Bina Taruna Gorontalo

VOLUME 7 NO. 2 Desember 2019
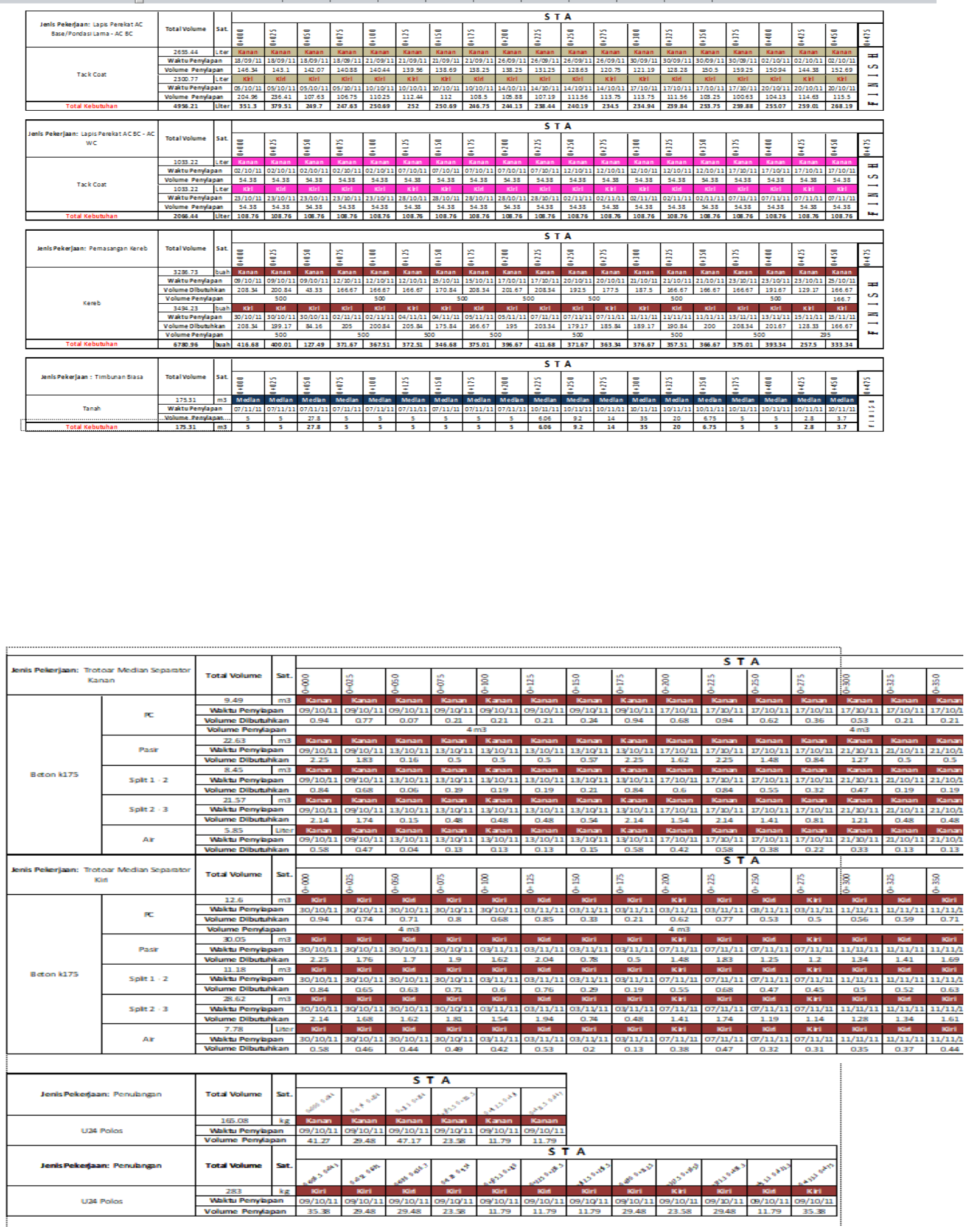

[Penjadwalan dan alokasi material dengan metode (lob) pada proyek pelebaran jalan : ....; Mohamad Januar Fuad] 